Egyptian Journal of Aquatic Biology \& Fisheries

Zoology Department, Faculty of Science,

Ain Shams University, Cairo, Egypt.

ISSN $1110-6131$

Vol. 23(4): 685 - 695 (2019)

www.ejabf.journals.ekb.eg

\title{
Community structure of crusteacean Zooplankton in the River Nile at Esna Barrages, Upper Egypt.
}

\author{
Ahmad H. Obuid-Allah ${ }^{1}$, Ahmed S. Moustafa ${ }^{2}$, Wafaa A. Mohammad ${ }^{3}$, \\ El-Amier H. M. Hussien ${ }^{2} *$ and Azza M. Gaber ${ }^{2}$ \\ 1- Zoology Department, Faculty of Science, Assiut University, Egypt. \\ 2- Zoology Department, Faculty of Science, South Valley University, Qena, Egypt \\ 3- Zoology Department, Faculty of Science, New Valley University, Egypt \\ *Corresponding author: elameer.hussien@sci.svu.edu.eg
}

\section{ARTICLE INFO}

Article History:

Received: Nov. 9, 2019

Accepted: Nov.29, 2019

Online: Dec. 2019

Keywords:

Zooplankton

Crustacea

Community structure

Esna barrage

Upper Egypt

River Nile

\begin{abstract}
Zooplanktons are major components in the trophic dynamics of freshwater ecosystems. The present study was carried out on the River Nile at Esna barrages, Upper Egypt which located between $25^{\circ} 19^{\prime} 03.5^{\prime \prime} \mathrm{N}$ and $32^{\circ} 33^{\prime} 19.5^{\prime \prime E}$. Samples were collected from six sites up and down stream of the barrage during one year extended from October 2018 till September 2019. The study revealed that the total number of zooplankton community collected was $\left(36367 \mathrm{indv} / \mathrm{m}^{3}\right)$. The collected zooplankton could be assigned to three different groups (Cladocera, Copepoda, and Ostracoda) which included 37 species belonging to 27 genera that fall in 10 families. The highest value of total abundance of zooplankton was recorded during winter and the lowest value was recorded during summer. The total density of zooplankton community was recorded at site 1 which is located upstream (9396 indv/ $/ \mathrm{m}^{3}$ ), while the lowest value was recorded at site 4 (downstream) $\left(4186 \mathrm{indv} / \mathrm{m}^{3}\right)$. Cladocera was the dominant group; it represented about $87.5 \%$ of the total density followed by Copepoda and Ostracoda. Taxa richness reached the highest peak value (29 taxa) at upstream, while the highest peak value was (25 taxa) at downstream. Shannon- wiener's diversity index ranged between (2.06) and (2.33) at upstream while it ranged between (1.95) and (2.45) at downstream.
\end{abstract}

\section{INTRODUCTION}

The new Esna barrage was constructed on the River Nile in 1995 and equipped with a hydropower station. The distance between the new Esna barrage, which is located downstream the old barrage, is $1.1 \mathrm{~km}$. Moffat et al. (1990) and Gray (1992) reported that the construction of barrages on a River leads to change the hydraulic regime of that River by increasing water depths and reducing velocities in areas of developed backwater curves.

The word plankton is being initial authored by Victor Henson in 1887 to assign the heterogeneous gathering of suspended microscopic materials, minute organisms and debris in water that move by the helping of winds, currents and tides (Pavan et al., 2017). Zooplankton is considered as the major components in the trophic dynamics of freshwater ecosystems. They occupy an intermediate position in the food chain and indicate the environmental status (Fishar et al., 2019). 
Zooplankton plays a vital role in matter and energy flow in most river ecosystems and it is essential in maintaining their balance. Zooplanktons are good indicator for future fisheries health, where they transfer primary productivity to fish and other consumers (Dejen et al., 2004 and Davies et al., 2009).

Zooplankton species composition changes from one area to another within the same geographical areas (Jonathan et al., 2000). Zooplankton species composition varies from one season to another influenced by the physico-chemical and biological factors (Perumal et al., 2009). Within given water body, mostly of certain zooplankton species may be found in certain areas and may be less or absent in another areas (Kapusta, 2013). Ezekiel et al. (2011) reported that dominance of certain zooplankton species due to naturally varying flows of water and sediment in aquatic systems.

Previous studies on various aspects of zooplankton were carried out in the River Nile by many authors and authorities. However, to the best of the present authors knowledge, the present study is the first one that focuses on survey of crustacean zooplankton community in the River Nile at Esna barrages, Upper Egypt.

\section{MATERIALS AND METHODS}

\section{Description of the Study Area:}

The present study was carried out at the new Esna barrage, Upper-Egypt which is located $1.1 \mathrm{~km}$ downstream the old barrages. The barrage lies between $25^{\circ} 19^{\prime} 03.5^{\prime \prime} \mathrm{N}$ latitude and $32^{\circ} 33^{\prime} 19.5^{\prime \prime} \mathrm{E}$ longitude. Six different locations were randomly chosen; three sites (Sites 1-3) located after the old barrages (Upstream) and the other three sites (Sites4- 6) located after the new barrages (Downstream) (Fig. 1). The latitude and longitude coordinates of sampling stations were recorded using the survey vessel's Garmin, Global Positioning System (GPS) unit navigation system (Table 1).

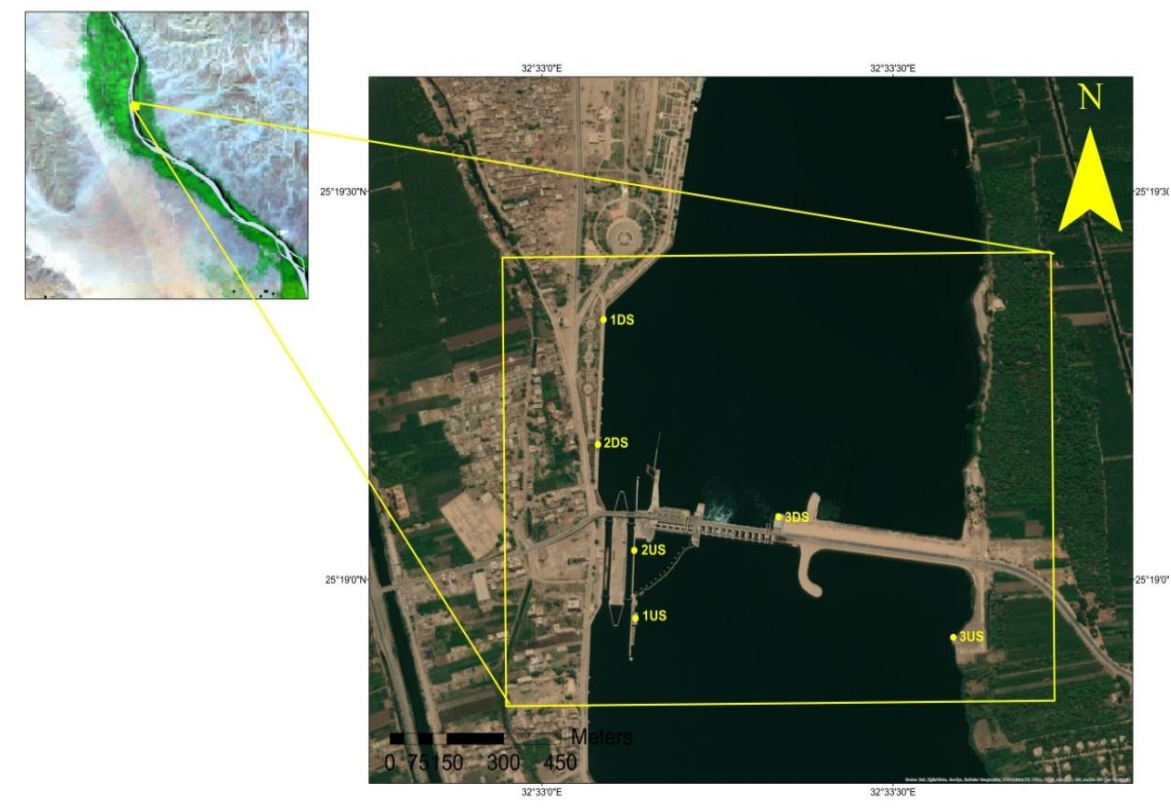

Fig. 1: A map of the River Nile at Upper Egypt, showing the locations of studied sites. Sites 1- 3 U.S. represent upstream while sites 1-3 D.S. represent downstream. 
Table 1: The coordinates and localities of sampling locations at upstream and downstream of the Esna barrages on the Nile River.

\begin{tabular}{|c|c|}
\hline Sample sites & GPS coordinates \\
\hline Site 1 upstream east & $25^{\circ} 18^{\prime} 57.74^{\prime \prime N ~} 32^{\circ} 33^{\prime} 7.94 " \mathrm{E}$ \\
\hline Site 2 upstream east & $25^{\circ} 19^{\prime} 2.24^{\prime \prime} \mathrm{N} \quad 32^{\circ} 33^{\prime} 8.15^{\prime \prime} \mathrm{E}$ \\
\hline Site 3 upstream west & $25^{\circ} 18^{\prime} 55.47^{\prime \prime} \mathrm{N} \quad 32^{\circ} 33^{\prime} 35.28^{\prime \prime} \mathrm{E}$ \\
\hline Site 4 downstream east & $25^{\circ} 19^{\prime} 10.75^{\prime \prime} \mathrm{N} 32^{\circ} 33^{\prime} 5.00^{\prime \prime} \mathrm{E}$ \\
\hline Site 5 downstream east & $25^{\circ} 19^{\prime} 20.07^{\prime \prime N} 32^{\circ} 33^{\prime} 5.49^{\prime \prime} \mathrm{E}$ \\
\hline Site 6 downstream west & $25^{\circ} 19^{\prime} 4.96^{\prime \prime} \mathrm{N} 32^{\circ} 33^{\prime} 21.02^{\prime \prime} \mathrm{E}$ \\
\hline
\end{tabular}

\section{Zooplankton sampling:}

Plankton net was used to collect samples; cone-shaped net is made of nylon cloth with about 153 micron mesh size which permits water to pass through but is fine enough to filter out organisms. Minute plankton is collected and can be observed in the removable, clear conical tube $(50 \mathrm{ml}$.) at the end of the net. A sturdy stainless steel ring and harness keep the mouth of the net open while it is being pulled through the water. It has a $(12.7 \mathrm{~cm})$ diameter mouth, and is $(38 \mathrm{~cm})$ long. The zooplankton samples were stored in plastic bottles containing 95\% ethanol. The bottles were kept and transported to the laboratory, Department of Zoology, Faculty of Science, South Valley University, Qena.

\section{Identification of zooplankton:}

The collected zooplankton species were identified according to different keys: To identify Cladocera, the following keys were used: Brooks (1959) and Obuid-Allah (2001). Copepoda were identified according to Wilson and Yeatman (1959) and Obuid-Allah (2001). Ostracoda were identified according to Fangary (2003).

\section{Samples treatment:}

The dominance structure of species was calculated according to Engelmann's classification (Engelmann, 1978) as subrecedent (below 1.3\%), recedent (1.3-3.9\%), subdominant (4-12.4\%), dominant (12.5-39.9\%), eudominant (40-100\%). Shannon wiener diversity index $\left(\mathrm{H}^{\prime}\right)$ was calculated to show zooplankton diversity within the collected community by using shannon-wiener equation: $\mathrm{H}^{\prime}=-\Sigma$ pi (lnpi), where pi is the proportion of individuals belonging to the $\mathrm{i}^{\text {th }}$ species. Zooplankton richness of the community was calculated.

\section{Statistical analysis:}

Analysis of Variance on SPSS software package (SYSTAT statistical program, version 23) was used to test the present data. In the case of significant differences, the Multiple Range Comparisons (Least Significant Difference; LSD) was selected from the Post Hoc window on the same statistical package to detect the distinct variances between means.

\section{RESULTS}

A total number of $36367 \mathrm{indv} / \mathrm{m}^{3}$ of different taxa of zooplankton were collected from six different sites located at Esna barrages. The collected zooplankton taxa belong to 3 main groups: (21 taxa of Cladocera, 13 taxa of Copepoda and 3 taxa of Ostracoda). Taxa collected were assigned in 28 genera and 35 species that fall in 10 families. In addition to Copepodite stage and Nauplius stage. The identified families included the following: Six families belonging to Cladocera: Bosminidae, Daphniidae, Ilyocryptidae, Macrothricidae, Chydoridae, Sididae. Three families belonging to Copepoda: Diaptomidae, Cyclopidae, Miraciidae. One family belongs to Ostracoda:Cyprididae. These families varied in their numbers and frequencies of 
occurrence according to the site. The most abundant family was Chydoridae, which represented the highest number during the whole period of study $\left(19826 \mathrm{indv} / \mathrm{m}^{3}\right)$ and embraced most of zooplankton taxa (13 species), but the lowest number was represented by Family Sididae $\left(26 \mathrm{indv} / \mathrm{m}^{3}\right)$, which embraced one species in the same period of study Table (2).

Table 2: The identified species from the six investigated sites during the period of investigation.

\begin{tabular}{|c|c|c|}
\hline Division & Family & Species \\
\hline \multirow[t]{21}{*}{ Cladocera } & Family: Bosminidae & Bosmina longirostris \\
\hline & Family: Daphniidae & Simocephalus expinosus \\
\hline & & Simocephalus vetulus \\
\hline & & Ceriodaphnia reticulata \\
\hline & & Daphnia longispina \\
\hline & Family: Ilyocryptidae & Ilyocryptus sordidus \\
\hline & Family: Macrothricidae & Macrothrix laticornis \\
\hline & Family: Chydoridae & Alona bukobensis a \\
\hline & & Alona bukobensis $b$ \\
\hline & & Alona bukobensis c \\
\hline & & Alona rectangular \\
\hline & & Alona sp. \\
\hline & & Camptocercus australis \\
\hline & & Leydigia quadrangularis \\
\hline & & Oxyurella sp. \\
\hline & & Chydorus sphaericus \\
\hline & & Disparalona rostrata. \\
\hline & & Pleuroxus aduncus \\
\hline & & Pleuroxus letourneuxi \\
\hline & & Dunhevedia crassa \\
\hline & Family: Sididae & Diaphanosoma birgei \\
\hline \multirow[t]{13}{*}{ Copepoda } & 1-Order: Calanoida & Thermodiaptomus galebi \\
\hline & Family: Diaptomidae & \\
\hline & 2-Order: Cyclopoida & Mesocyclops ogunnus \\
\hline & Family: Cyclopidae & Thermocyclops consimilis \\
\hline & & Thermocyclops neglectus \\
\hline & & Tropocyclops confinis \\
\hline & & Macrocyclops albidus \\
\hline & & Microcylops varicans \\
\hline & & Microcylops linjanticus \\
\hline & & Ectocyclops phaleratus \\
\hline & & Afrocyclops gibsoni \\
\hline & 3-Order: Harpacticoida & Shizopera nilotica \\
\hline & Family: Miraciidae & \\
\hline \multirow[t]{3}{*}{ Ostracoda } & Family: Cyprididae & Cypridopsis vidua \\
\hline & & Potamocypris variegate \\
\hline & & Candona sp. \\
\hline
\end{tabular}

Cladocera was the most abundant group of zooplankton in all investigated sites constituting (31806 indv/ $\left./ \mathrm{m}^{3}\right)$ followed by Copepoda $\left(4228 \mathrm{indv} / \mathrm{m}^{3}\right)$ and Ostracoda (333 indv/ $/ \mathrm{m}^{3}$ ) (Fig.2). Considering the number of each taxa of zooplankton collected from all sites, it was observed that the maximum number was collected from Disparalona rostrata (9652 indv/ $/ \mathrm{m}^{3}$, constituting $26.54 \%$ of the total number), while Daphnia longispina, Alona sp. Oxyurella sp. were the least species in number since (4 indv $/ \mathrm{m}^{3}$ for each one, constituting $0.01 \%$ from the total number) (Table 3 ). 


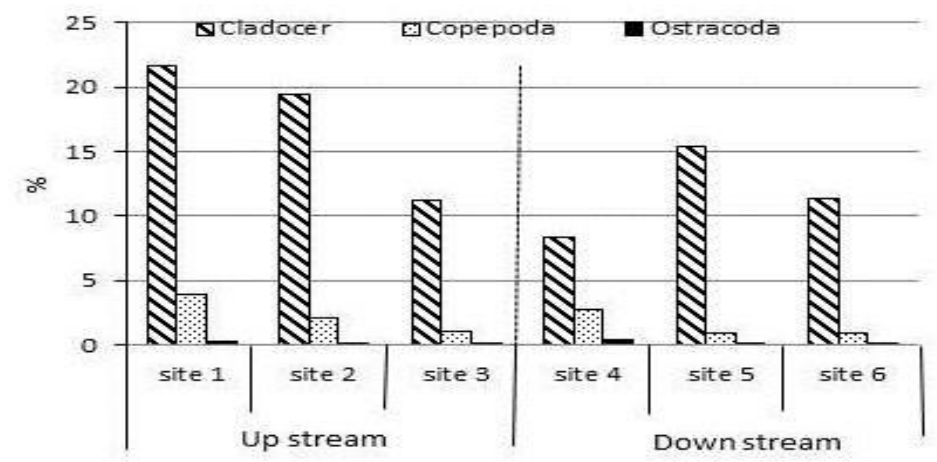

Fig. 2: The abundance of the collected zooplankton (indv/ $\mathrm{m}^{3}$ ) in the upstream and downstream sites.

Table 3: Total number and percentage of zooplankton taxa collected from all investigated sites during the period of investigation.

\begin{tabular}{|c|c|c|c|c|c|c|c|c|}
\hline \multirow[t]{2}{*}{ Taxa } & \multicolumn{8}{|c|}{ Site } \\
\hline & $\begin{array}{c}\text { Site 1 } \\
\text { indv/m } \\
\end{array}$ & $\begin{array}{c}\text { Site } 2 \\
\text { indv } / \mathbf{m}^{3}\end{array}$ & $\begin{array}{c}\text { Site } 3 \\
\text { indv } / \mathbf{m}^{3}\end{array}$ & $\begin{array}{c}\text { Site } 4 \\
\text { indv/ } / \mathbf{m}^{3}\end{array}$ & $\begin{array}{c}\text { Site } 5 \\
\text { indv/. } \mathbf{m}^{3}\end{array}$ & $\begin{array}{c}\text { Site } 6 \\
\text { indv/ } / \mathbf{m}^{3}\end{array}$ & Total & $\%$ \\
\hline \multicolumn{9}{|l|}{ Cladocera } \\
\hline Bosmina longirostris & 1864 & 952 & 117 & 318 & 311 & 218 & 3780 & 10.39 \\
\hline Simocephalus expinosus & 321 & 133 & 0 & 164 & 116 & 9 & 743 & 2.04 \\
\hline Simocephalus vetulus & 33 & 46 & 13 & 16 & 42 & 13 & 163 & 0.45 \\
\hline Ceriodaphnia reticulate & 962 & 449 & 143 & 746 & 908 & 1299 & 4507 & 12.39 \\
\hline Daphnia longispina & 0 & 0 & 0 & 0 & 0 & 4 & 4 & 0.01 \\
\hline Ilyocryptus sordidus & 176 & 182 & 216 & 126 & 68 & 119 & 887 & 2.44 \\
\hline Macrothrix laticornis & 21 & 54 & 0 & 151 & 1580 & 63 & 1869 & 5.14 \\
\hline Alona bukobensis a & 13 & 95 & 389 & 0 & 53 & 27 & 577 & 1.59 \\
\hline Alona bukobensis b & 7 & 17 & 92 & 19 & 0 & 20 & 155 & 0.43 \\
\hline Alona bukobensis c & 423 & 742 & 447 & 39 & 44 & 82 & 1777 & 4.89 \\
\hline Alona rectangular & 51 & 9 & 66 & 0 & 0 & 0 & 126 & 0.35 \\
\hline Alona sp. & 0 & 4 & 0 & 0 & 0 & 0 & 4 & 0.01 \\
\hline Camptocercus australis & 63 & 39 & 127 & 20 & 27 & 15 & 291 & 0.8 \\
\hline Leydigia quadrangularis & 0 & 0 & 0 & 7 & 0 & 0 & 7 & 0.02 \\
\hline Oxyurella sp. & 4 & 0 & 0 & 0 & 0 & 0 & 4 & 0.01 \\
\hline Chydorus sphaericus & 1974 & 926 & 1637 & 506 & 1358 & 523 & 6924 & 19.04 \\
\hline Disparalona rostrata. & 1866 & 3362 & 826 & 922 & 1102 & 1574 & 9652 & 26.54 \\
\hline Pleuroxus aduncus & 0 & 7 & 0 & 0 & 0 & 13 & 20 & 0.05 \\
\hline Pleuroxus letourneuxi & 0 & 0 & 0 & 0 & 0 & 13 & 13 & 0.04 \\
\hline Dunhevedia crassa & 91 & 46 & 0 & 0 & 13 & 127 & 277 & 0.76 \\
\hline Diaphanosoma birgei & 4 & 13 & 0 & 0 & 0 & 9 & 26 & 0.07 \\
\hline \multicolumn{9}{|l|}{ Copepoda } \\
\hline Thermodiaptomus galebi & 224 & 171 & 20 & 175 & 102 & 110 & 802 & 2.21 \\
\hline Mesocyclops ogunnus & 446 & 166 & 176 & 422 & 133 & 128 & 1471 & 4.04 \\
\hline Thermocyclops consimilis & 125 & 127 & 13 & 51 & 45 & 28 & 389 & 1.07 \\
\hline Thermocyclops neglectus & 0 & 4 & 0 & 7 & 9 & 0 & 20 & 0.05 \\
\hline Tropocyclops confinis & 38 & 24 & 9 & 40 & 13 & 0 & 124 & 0.34 \\
\hline Macrocyclops albidus & 13 & 0 & 0 & 13 & 0 & 0 & 26 & 0.07 \\
\hline Microcylops varicans & 48 & 38 & 31 & 13 & 0 & 24 & 154 & 0.42 \\
\hline Microcylops linjanticus & 231 & 49 & 22 & 103 & 18 & 0 & 423 & 1.16 \\
\hline Ectocyclops phaleratus & 0 & 0 & 0 & 0 & 13 & 0 & 13 & 0.04 \\
\hline Afrocyclops gibsoni & 53 & 0 & 8 & 0 & 0 & 0 & 61 & 0.17 \\
\hline Shizopera nilotica & 105 & 46 & 22 & 53 & 0 & 31 & 257 & 0.71 \\
\hline Copepodite stage & 136 & 126 & 55 & 110 & 11 & 28 & 466 & 1.28 \\
\hline Nauplius stage & 0 & 4 & 18 & 0 & 0 & 0 & 22 & 0.06 \\
\hline \multicolumn{9}{|l|}{ Ostracoda } \\
\hline Cypridopsis vidua & 54 & 24 & 8 & 158 & 7 & 13 & 264 & 0.73 \\
\hline Potamocypris variegate & 43 & 0 & 0 & 7 & 4 & 0 & 54 & 0.15 \\
\hline Candona sp. & 7 & 4 & 0 & 0 & 0 & 4 & & 0.04 \\
\hline Total & 9396 & 7859 & 4455 & 4186 & 5977 & 4494 & 36367 & \\
\hline
\end{tabular}


Concerning monthly fluctuations abundance of zooplankton in all investigated sites, it was found that the maximal number was collected during March (7125 indv $/ \mathrm{m}^{3}$ specimens, constituting $19.59 \%$ from the total number), while, the lowest number of the populations was collected during May, $\left(617 \mathrm{indv} / \mathrm{m}^{3}\right.$, consisting $1.70 \%$ from the total number). The most favorable locality was site 1 since the maximum number of specimens was collected reached $\left(9396 \mathrm{indv} / \mathrm{m}^{3}\right.$, constituting $25.84 \%$ of the overall total number), whereas site 4 was the least favorable one, $\left(4186 \mathrm{indv} / \mathrm{m}^{3}\right.$ and constituting $11.51 \%$ of the overall total number). (Table 4 ).

Table 4: Total number of zooplankton taxa collected from all investigated sites during the period of investigation.

\begin{tabular}{lccccccccccccc}
\hline & Oct. & Nov. & Dec. & Jan. & Feb. & Mar. & Apr. & May & Jun. & Jul. & Aug. & Sep. & Total \\
\hline Site 1 & 173 & 1207 & 1934 & 642 & 1310 & 2382 & 402 & 169 & 29 & 398 & 465 & 285 & $\mathbf{9 3 9 6}$ \\
Site 2 & 234 & 825 & 1184 & 673 & 1490 & 2360 & 146 & 303 & 121 & 21 & 146 & 356 & $\mathbf{7 8 5 9}$ \\
Site 3 & 216 & 880 & 969 & 260 & 1221 & 497 & 0 & 11 & 105 & 81 & 22 & 193 & $\mathbf{4 4 5 5}$ \\
Site 4 & 200 & 518 & 567 & 132 & 933 & 353 & 245 & 78 & 521 & 156 & 188 & 295 & $\mathbf{4 1 8 6}$ \\
Site 5 & 134 & 154 & 873 & 665 & 443 & 869 & 1843 & 56 & 665 & 87 & 43 & 145 & $\mathbf{5 9 7 7}$ \\
Site 6 & 111 & 205 & 81 & 194 & 751 & 664 & 662 & 0 & 921 & 101 & 48 & 756 & $\mathbf{4 4 9 4}$ \\
Total & 1068 & 3789 & 5608 & 2566 & 6148 & 7125 & 3298 & 617 & 2362 & 844 & 912 & 2030 & $\mathbf{3 6 3 6 7}$ \\
\% & 2.94 & 10.42 & 15.42 & 7.06 & 16.91 & 19.59 & 9.07 & 1.70 & 6.49 & 2.32 & 2.51 & 5.58 & $\mathbf{1 0 0}$ \\
\hline
\end{tabular}

Regarding seasonal fluctuations of all six sites, it could be noticed that the maximal number was collected during winter (14322 indv/ $\mathrm{m}^{3}$, constituting $41.84 \%$ from the total number), and the minimal number was collected during summer (4118 indv $/ \mathrm{m}^{3}$, constituting $12.03 \%$ from the total number) (Fig.3).

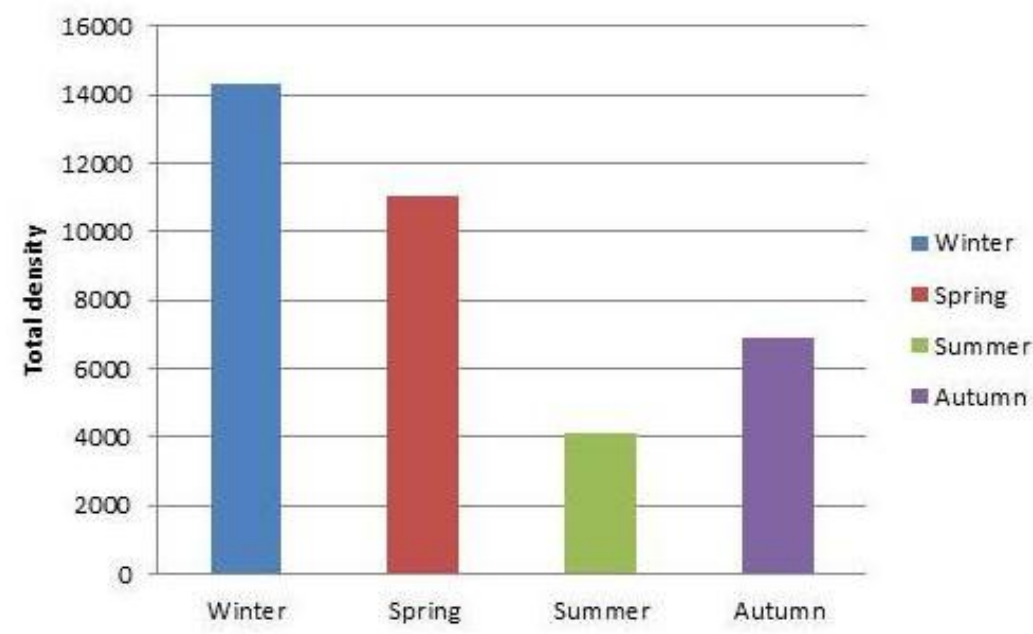

Fig. 3: Seasonal abundance of total density of zooplankton during the period of study.

In monthly fluctuations; the dominance structure of the collected species showed that there were 3 eudominant species, the Eudominant zooplankton taxa were: Ceriodaphnia reticulata (43.98\%), Chydorus sphaericus (43.06\%) and Mesocyclops ogunnus (40.74\%). The dominant species were 9 taxa: Bosmina longirostris (39.35\%), Disparalona rostrata (32.41\%), Ilyocryptus sordidus (29.63\%), Alona 
bukobensis c (20.37\%), Thermodiaptomus galebi (20.37\%), Copepodite stage (16.67\%) Thermocyclops consimilis (15.28\%), Simocephalus expinosus (12.5\%) and Shizopera nilotica (12.50\%). The subdominant species were 10 species: Microcylops linjanticus (11.11\%), Simocephalus vetulus (9.72\%), Camptocercus australis (8.80\%), Macrothrix laticornis (7.41\%), Cypridopsis vidua (7.41\%), Tropocyclops confinis (6.94\%), Microcylops varicans (6.48\%), Alona bukobensis a (5.56\%), Alona bukobensis $b(5.09 \%)$. There were 4 recedent taxa: Dunhevedia crassa $(3.70 \%)$, Alona rectangular (2.78\%), Potamocypris variegate (2.78\%), Nauplius stage (2\%), Thermocyclops neglectus (1.39\%) and Fabaeformiscandona holzkampfi (1.39\%) (Table 5).

Table 5: The frequency, the percentage $(\mathrm{F}, \%)$ and the dominancy of the zooplankton taxa at upstream and downstream sites during the period of investigation.

\begin{tabular}{|c|c|c|c|c|c|c|c|c|c|}
\hline \multirow{3}{*}{ Taxa } & \multicolumn{9}{|c|}{ Site } \\
\hline & \multirow{2}{*}{$\frac{\text { Site 1 }}{\mathrm{F}}$} & \multirow{2}{*}{$\frac{\text { Site2 }}{\mathrm{F}}$} & \multirow{2}{*}{$\frac{\text { Site3 }}{\mathrm{F}}$} & \multirow{2}{*}{$\begin{array}{c}\text { Site4 } \\
\mathrm{F}\end{array}$} & \multirow{2}{*}{$\frac{\text { Site5 }}{\mathrm{F}}$} & \multirow{2}{*}{$\begin{array}{c}\text { Site6 } \\
\mathrm{F}\end{array}$} & \multicolumn{3}{|c|}{ Total } \\
\hline & & & & & & & $\mathrm{F}$ & $\%$ & Dominancy \\
\hline \multicolumn{10}{|l|}{ Cladocera } \\
\hline Bosmina longirostris & 24 & 19 & 4 & 11 & 14 & 13 & 85 & 39.35 & Dominant \\
\hline Simocephalus expinosus & 9 & 8 & 0 & 6 & 3 & 1 & 27 & 12.5 & Dominant \\
\hline Simocephalus vetulus & 6 & 7 & 1 & 2 & 4 & 1 & 21 & 9.72 & Subdominant \\
\hline Ceriodaphnia reticulata & 23 & 18 & 8 & 16 & 14 & 16 & 95 & 43.98 & Eudominant \\
\hline Daphnia longispina & 0 & 0 & 0 & 0 & 0 & 1 & 1 & 0.46 & Subrecedent \\
\hline Ilyocryptus sordidus & 14 & 11 & 8 & 10 & 9 & 12 & 64 & 29.63 & Dominant \\
\hline Macrothrix laticornis & 3 & 2 & 0 & 5 & 2 & 4 & 16 & 7.41 & Subdominant \\
\hline Alona bukobensis a & 1 & 5 & 4 & 0 & 1 & 1 & 12 & 5.56 & Subdominant \\
\hline Alona bukobensis b & 1 & 2 & 4 & 3 & 0 & 1 & 11 & 5.09 & Subdominant \\
\hline Alona bukobensis c & 12 & 8 & 11 & 4 & 3 & 6 & 44 & 20.37 & Dominant \\
\hline Alona rectangular & 3 & 1 & 2 & 0 & 0 & 0 & 6 & 2.78 & Recedent \\
\hline Alona sp. & 0 & 1 & 0 & 0 & 0 & 0 & 1 & 0.46 & Subrecedent \\
\hline Camptocercus australis & 3 & 5 & 6 & 1 & 1 & 3 & 19 & 8.80 & Subdominant \\
\hline Leydigia quadrangularis & 0 & 0 & 0 & 1 & 0 & 0 & 0 & 0.46 & Subrecedent \\
\hline Oxyurella sp. & 1 & 0 & 0 & 0 & 0 & 0 & 1 & 0.46 & Subrecedent \\
\hline Chydorus sphaericus & 19 & 14 & 16 & 16 & 15 & 13 & 93 & 43.06 & Eudominant \\
\hline Disparalona rostrata. & 13 & 13 & 11 & 12 & 9 & 12 & 70 & 32.41 & Dominant \\
\hline Pleuroxus aduncus & 0 & 1 & 0 & 0 & 0 & 1 & 2 & 0.93 & Subrecedent \\
\hline Pleuroxus letourneuxi & 0 & 0 & 0 & 0 & 0 & 1 & 1 & 0.46 & Subrecedent \\
\hline Dunhevedia crassa & 4 & 2 & 0 & 0 & 1 & 1 & 8 & 3.70 & Recedent \\
\hline Diaphanosoma birgei & 1 & 1 & 0 & 0 & 0 & 0 & 2 & 0.93 & Subrecedent \\
\hline \multicolumn{10}{|l|}{ Copepoda } \\
\hline Thermodiaptomus galebi & 12 & 9 & 2 & 7 & 8 & 6 & 44 & 20.37 & Dominant \\
\hline Mesocyclops ogunnus & 22 & 13 & 11 & 18 & 13 & 11 & 88 & 40.74 & Eudominant \\
\hline Thermocyclops consimilis & 8 & 10 & 1 & 5 & 5 & 4 & 33 & 15.28 & Dominant \\
\hline Thermocyclops neglectus & 0 & 1 & 0 & 1 & 1 & 0 & 3 & 1.39 & Recedent \\
\hline Tropocyclops confinis & 5 & 3 & 1 & 5 & 1 & 0 & 15 & 6.94 & Subdominant \\
\hline Macrocyclops albidus & 1 & 0 & 0 & 1 & 0 & 0 & 2 & 0.93 & Subrecedent \\
\hline Microcylops varicans & 4 & 3 & 2 & 1 & 0 & 4 & 14 & 6.48 & Subdominant \\
\hline Microcylops linjanticus & 9 & 5 & 2 & 5 & 3 & 0 & 24 & 11.11 & Subdominant \\
\hline Ectocyclops phaleratus & 0 & 0 & 0 & 0 & 1 & 0 & 1 & 0.46 & Subrecedent \\
\hline Afrocyclops gibsoni & 1 & 0 & 1 & 0 & 0 & 0 & 2 & 0.93 & Subrecedent \\
\hline Shizopera nilotica & 11 & 5 & 3 & 5 & 0 & 3 & 27 & 12.50 & Dominant \\
\hline Copepodite stage & 9 & 9 & 4 & 8 & 2 & 4 & 36 & 16.67 & Dominant \\
\hline Nauplius stage & 1 & 2 & 1 & 0 & 0 & 0 & 4 & 1.85 & Recedent \\
\hline \multicolumn{10}{|l|}{ Ostracoda } \\
\hline Cypridopsis vidua & 5 & 3 & 1 & 4 & 1 & 2 & 16 & 7.41 & Subdominant \\
\hline Potamocypris variegata & 4 & 0 & 0 & 1 & 1 & 0 & 6 & 2.78 & Recedent \\
\hline Candona sp. & 1 & 1 & 0 & 0 & 0 & 1 & 3 & 1.39 & Recedent \\
\hline
\end{tabular}

Taxa Richness and Shannon diversity index.

In upstream sites, the highest value for Shannon- wiener's diversity index were recorded in sites 1,2 , while the lowest value was recorded in site 3 . In downstream sites the highest value of Shannon- wiener's diversity index was recorded in site 4 and 
the lowest was in site 6. The taxa richness at downstream sites were usually lower than upstream sites (Fig. 4).

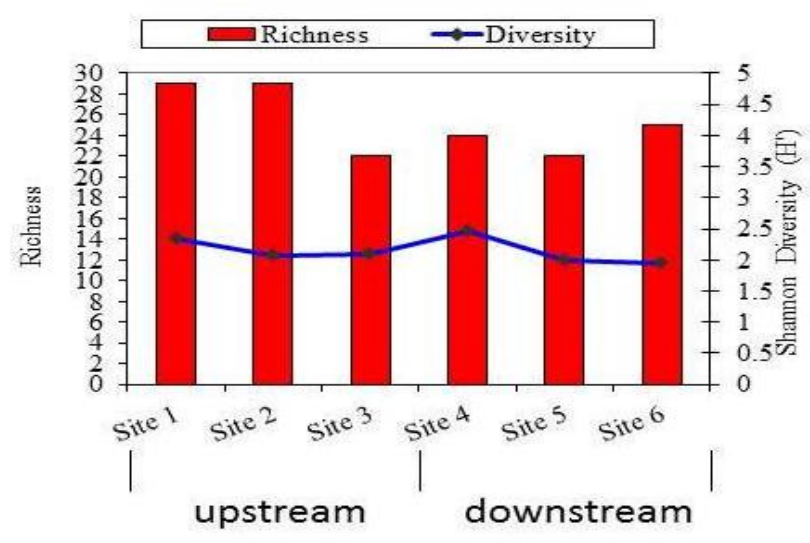

Fig. 4: Taxa richness and Shannon diversity of the total zooplankton in the up and downstream sites during the period of investigation.

\section{DISCUSSION}

In the present study, thirty seven zooplankton taxa had been recorded at six investigated sites (upstream and downstream) during the period of investigation. They were represented, by common freshwater crustacean groups, Cladocera (21 taxa), Copepoda (13 taxa), and Ostracoda (3 taxa).

The study indicated that, the total density of crustacean zooplankton showed the highest peak during winter and lowest peak during summer. This result agrees with Mohammad (2016) who studied zooplankton inhabiting the River Nile at Assiut, Egypt and concluded that zooplankton attained the highest total average density during winter and the minimum value was at summer. The high abundance recorded during winter may be due to that low temperature is unfavorable for predation. Previous studies indicated increase of predation by planktivorous fish during summer months compared to spring (De Stasio, 1991; Flik and Ringelberg, 1993).

Cladocera was the most dominant group; its total density was represented by 87.5\%. This result agrees with that recorded in the Nile water by mohammad (2008), Mohammad et al., (2016) and Abdel hady (2013). The present study showed that the highest peak density of Cladocera was noticed during winter, while the lowest peak was during summer. The increase in the density of Cladocera in winter could be due to the increased oxygen content of the water because of decreased temperature and increased water movement. This result agrees with Zaghloul (1985), who illustrated that the limnoplanktonic forms of Cladocera require high oxygen concentration. Green (1962) indicated flourishing of Cladocera during low temperature seasons and most of large cladoceran species don't produce in warm months but can produce in winter-spring. Fakayode (2005) estimated that dissolved oxygen is very crucial for survival of aquatic organisms and it is also used to evaluate the degree of freshness of Alaro River, Nigeria. El-Bassat (2002) mentioned that, temperature plays a major role in the distribution of Cladocera and most cladoceran species prefer low temperature. Fishar et al. (2019) reported that in El-Rayah El-Behery, the highest population density of Cladocera was recorded in winter while the lowest population density was observed during summer. 
The decrease in density of Cladocera during summer may explain that high temperature is an unfavorable for Cladocera. Abd El-Karim (1999) and Bedair (2006) mentioned that, the decreasing in the density of Cladocera populations during summer may due to flourish of blue green algae and dinoflagellates which lead to the inhibition of Cladocera filtering rate. Helal (1981) demonstrated that summer and autumn were apparently the period of the paucity of the cladocerans.

Ceriodaphnia reticulata was the eudominant species in cladoceran group during the period of investigation, this result is in agreement with Mohmoud (1995) who reported that Ceriodaphnia reticulata was an abundant species, constituted $23.5 \%$ of the total number. Obuid- Allah (1990a) made a survey of freshwater Cladocera at 11 districts including 25 sites in Egypt and estimated that Ceriodaphnia reticulata was accessory species.

The present work indicated that the total density of zooplankton was recorded at sites located upstream of the old barrages on the River Nile. It was $\left(21710 \mathrm{Indv} / \mathrm{m}^{3}\right)$ constituting $59.70 \%$ of the total zooplankton at both streams. However, the total density of zooplankton recorded at sites located downstream of the old barrages on the River Nile was $\left(14657 \mathrm{Indv} / \mathrm{m}^{3}\right.$ ) constituting $40.30 \%$ of the total zooplankton at both streams. These differences in zooplankton community between upstream and downstream pointed to the impacts of the new Esna barrages construction. Previous studies conducted by Poiner and Kennedy (1984) revealed that a further effect of dredging may be that the disturbance of sediments, releases sufficient organic materials to enhance the species diversity and population density of organisms outside the immediate zone of deposition of suspended material.

The mean value of Shannon diversity index $(\mathrm{H})$ recorded slight fluctuations among different studied sites during the period of investigation. In the upstream the value of index $(\mathrm{H})$ ranged from (2.33) in site 1 to (2.06) in site2. On the opposite side, the value of index $(\mathrm{H})$ at downstream increased from (2.45) in site 4 to (1.95) in site 6. In comparing upstream and downstream, the values of index $(\mathrm{H})$ were $(2.17)$ \& (2.13); respectively. Kerkhoff (2010) reported that typical values are generally between 1.5 and 3.5 in most ecological studies, and the index is rarely greater than 4 .

From the above mentioned results, it was concluded that the diversity from the studied upstream sites is much higher than from the sites located downstream. This result is an expected one and mostly due to the effect of the barrage since the presence of the barrage makes the conditions of the upstream looks like a lake condition which helps many organisms to flourish and make true associations. Attayed and Bozelli (1998) reported that changes in zooplankton diversity are known to be significant indicators of environmental disturbance.

\section{REFERENCES}

Abd El-Karim, M. S. (1999). Phytoplankton dynamic and its productivity in Damietta Branch. M. Sc. Thesis, Girls College for Arts, Education \& Science. Ain Shams Univ., $202 \mathrm{pp}$.

Abdel-Hady, E. M. N. (2013). Studies on the influence of the High Dam on the quantity and quality of aquatic Arthropods (Crustacean Zooplankton and Insects) in Aswan, Egypt.M.Sc. thesis, , Dept. Zool., Fac.Sci. Assiut univ., Egypt.

Gray, A. J. (1992). The ecological impact of the estuarine barrages. The British ecological society by field studies council (issue no 3 ). 
Attayed, J. L. and Bozelli, R. L. (1998). Assessing the indicator properties of zooplankton assemblages to disturbance gradients by canonical correspondence analysis. Canad.j.Fish.Aqua.Sci., 55: 1789-1797.

Attia, K. and El- Sersawy, H. (2005). River regulation downstream new Esna barrage barrage using mathematical model mathematical model. Ninth International Water Technology Conference.

Bedair, S. M. (2006). Environmental studies on zooplankton and phytoplankton in some polluted areas of the River Nile and their relation with feeding habit of fish. Ph. D. Thesis, Fac. Of Sci. Zagazig Uni.

Brooks, J. L. (1959). Cladocera In : Fresh water biology, 2nd ed. Edmondson W. T. New York, pp 587-656. John Wiley and sons.

Davies, O. A.; Tawari, C. C. and Abowei, J. F. N. (2009). Zooplankton of Elechi Creek, Niger Delta Nigeria. Environ.Ecol. 26(4c): 2441-2346.

De Stasio, B. T. (1991). Diel vertical and horizontal migration by zooplankton: population budgets and the diurnal deficit. Bull. Mar. Sci. 53: 44-64.

Dejen, E.; Ngweheng, I.; Nogelkerke, I. and Sibbing, E. (2004). Temporal and spatial distribution of microcrustacean Zooplankton in relation to turbidity and other environmental factors in large tropical lake (L. Tana, Ethiopia). Hydrobiol.513: 39-49.

El Gamal, F.; Hesham, M.; Shalaby, A. R. (2007). Country paper on harmonization and integration of water saving options in Egypt. In: Karam, F., Karaa, K., Lamaddalena, N., Bogliotti, C. (Eds.), Harmonization and Integration of Water Saving Options. Convention and Promotion of Water Saving Policies and Guidelines. CIHEAM/EU DG Research, Bari, pp. 81-90

El-Bassat, R. A. (2002). Ecological studies on zooplankton communities with particular reference to free living protozoans at River Nile - Damietta Branch. Ph. D. Thesis, Wom. Coll. For Arts, Educ. \& Sci., Ain Shams Univ.

Engelmann, H. D. (1978). Dominance classification of ground arthropods. Pedobiologia, 18: 378-380.

Ezekiel, E. N., Ogamba E. N. and Abowei, J. F. N. (2011). The zooplankton species composition and abundance in Sombreiro river, Niger Delta, Nigeria. Asian Journal of Agricultural Sciences, 3(3): 200 - 204.

Fakayode S. O. (2005). Impact of industrial effluents on water quality of the receiving Alaro River in Ibadan, Nigeria, Ajeam-Ragee, 10: 1-13.

Fangary, H. M. (2003). Taxonomical and Ecological studies on freshwater ostracods at Qena Governorate, Upper Egypt. M.Sc. thesis. Zool. Depart. Fac. Sci. Qena, South Vally Univ.

Fishar, M. R.; Mahmoud, N. H.; El- Feqy, F. A. and Gaber, K. M. G. (2019). Community Composition of Zooplankton in El-Rayah El-Behery, Egypt. Egyptian Journal of Aquatic Biology \& Fisheries. 23(1): 135 - 150.

Flik, B. G. and Ringelberg, J. (1993). Influence on food availability on the initiation of diel vertical migration (DVM) in Lake Maarsseveen. Ergeb. Limnol-Adv. Limnol., 39: 57-65.

Green, J. (1962). Zooplankton of the River Socoto. The Rotifera: The crustacea. Proc. Zod. Soc. London, 138(4): 414-453.

Helal, H. A. (1981). Studies on the zooplankton of Damietta branch of the River Nile north of El-Mansoura. M.Sc. thesis. Zool. Depart. Fac.Sci. Mansoura Univ., Egypt. 
Jonathan, B. S.; John, E. H.; Mathew, A. L. and Alloul, B. P. (2000). Local and regional zooplankton species richness: A scale independent test for saturation. Ecology 81(11): 3062 - 3073.

Kapusta, E. B. and Kapusta, A. (2013). Spatial and Diurnal distribution of Cladocera in beds of invasive Vallisneira spirallis and open water in heated lake. Acta Zoologica Bulgarica 65(2): 225 - 231.

Kerkhoff (2010). Measuring biodiversity of ecological communities. Ecology Lab Biology, 229pp.

Mahmoud, A. A. (1995). Taxonomical and ecological studies on freshwater fleas (Cladocera) in Qena governate. Ph.D.Thesis Zool.Depart.Fac.Sci.Qena,south valley Univ.Egypt.

Moffat, A. I. B.; Novak, P.; Naluri, C. and Narayanan. R. (1990). Hydraulic structure, London: Unwin Hyman.

Mohammad, W. A. (2008). Effect of pollution on freshwater zooplankton in Assiut, Egypt, M. Sc. thesis. Zool. Depart.Fac. Sci. Assiut Univ., Egypt.

Mohammed, W. A.; Obuid-Allah, A. H.; El-bakary, Z. A. Abd El-Wakeil K. F. (2016). Vertical distribution of zooplankton community in littoral zone of the River Nile at Assiut, Egypt. Eighth International Conference on Environment and Development in the Arab World.

Obuid-Allah, A. H. (1990). Seasonal variations in populations of Cladocera (Crustacea) of River Nile at Assuit, Egypt.Bull.Fac.Sci.,Assuit Univ.,19(1-E)4148.

Obuid-Allah, A. H. (2001). A review article on: Diversity of Cladocera and Copepoda in the freshwater bodies of Egypt and factors affecting it. Zool. Depart. Fac. Sci., Assiut Univ.

Pavan, M.; Gowri. P. and Benarjee, G. (2017). A Study on Zooplankton Diversity of Bhandam Cheruvu, Warangal, T.S. India. International Journal of Innovative Research in Science, Engineering and Technology, 5(9):17328-17332.

Perumal, N. V.; Rajkumar, M.; Perumal, P. and Rajasekar, T. K. (2009). Seasonal variations of plankton diversity in the Kaduviyar estuary, Nagapattinam, South east coast of India. Journal of Environmental Biology, 30(6): 1035 - 1046.

Poiner, I.R., and Kennedy R. (1984). Complex patterns of change in the macrobenthos of a large sandbank following dredging. Marine Biology, 78: 335-352

Ringelberg, J.; Flik, B. L. G.; Lindenaar, D. and Royackers, K. (1991). Diel vertical migration of Daphnia hyalina (sensulatiori) in Lake Maarsseveen. Part1. Aspects of seasonal and daily timing. Arch. Hydrobiol., 121: 129-145.

Wilson, M. S. and Yeatman, H. C. (1959). Free living copepod In: ward, H. B. and Whpple, C. C. Freshwater Biology, 2nd ed. 1959 (ed. W. T. Edondson), pp. 735-868.

Zaghloul, F. A. (1985). Seasonal variations of plankton in Lake Nasser. Ph.D. Thesis, Suez Canal Univ., Fac. Sci., Zoology Dept. 